\title{
Special Issue: Geography of Education
}

Silvie R. Kučerová

For the general public, but often also for many researchers, geography is sometimes a scientific discipline that is not so easy to define. Many people grope in the dark, having an idea that it is a field examining maps or setting the lists of cities with the highest number of inhabitants. So, what could be geography's relationship to the study of education?

The understanding of the spatial aspects or spatiality of the education can be regarded as geography's crucial contribution on this field. Geography does not encompass only the arrangement of phenomena on the Earth from the view of geometric space (measuring of distances or locating in the geographical system of coordinates) but also includes other characteristics in the spatial operationalisation. According to Siwek (2011), the geographical space is mainly characterised by interconnectedness with the man, the environment, society, and its activities.

Scale is another geographical specific of viewing the space (see, e.g. Leitner $\&$ Miller, 2007). It is a gnoseological approach of differentiating various hierarchical levels of Earth's surface and relations on this surface - from an individual and locations over larger regional levels to the global level. The third geography's specific, regionalisation, is related to the definition of such a system where regionalisation means the delimitation of space and delimitation and evaluation of regions (in more detail, see, e.g. Claval, 1998).

However, the increased interest in the operationalisation of space in the social sciences, including the educational sciences, seems to be a crucial aspect characterising various approaches of recent decades. Authors describe 
this interest in the spatial aspects of the studied phenomena as a (new) spatial turn in social sciences (e.g., Crang $\&$ Thrift, 2000). The Journal of Pedagogy also came up with a special issue $(1 / 2018)$ focusing on the Spatial approaches in research on early childhood education and care. Its content predominantly covered the specific segment of children's geography and childhood spaces (Holloway \& Pimlot-Wilson, 2014), maybe more focusing on micro-space and children's psychology of space (their mental maps).

Geography of education has become an umbrella field for our special issue $1 / 2020$. It is natural because it is the editor's parent field. On the other hand, geography connecting the elements of space has enabled to invite not only geographers but also researchers from other scientific disciplines who can express their thoughts on spatiality in education, hence deepening the interdisciplinary communication. Some authors met during regular conferences of the European Educational Research Association, especially within the network relating to the relationships between communities, families, and schooling. Other contributors met at the Interdisciplinary Symposium on Knowledge and Space, "Geographies of Schooling", in Heidelberg, Germany, in 2016. Consequently, they make up a diverse team of scholars from seven countries all over the world, most frequently working at the institutes of geography or institutes of education.

The primary focus of the Journal of Pedagogy is on research interests in educational sciences. For that reason, this special issue would aim to present the object of research in geography of education in its broadest way to the other disciplines. The plan was to cover all the following aspects of the discipline:

(1) Educational provision and restructuring (locational decisions in educational provision; restructuring the spatial organisation of education - new places for learning and alternative forms of education; spatial impacts of educational policy; inclusion - exclusion and accessibility of education; school market and school choice).

(2) Skills, employability, educational networks, knowledge in space (spatial aspects of social capital; relativity of importance of educational capital; spatial networking in education; clusters and knowledge mobility).

(3) Subjectivities in learning spaces (spatial representation in teaching aids; (re)construction of space through education; how national curricula shape regional and cultural perception; globalisation in education). 
The first article by authors from three different European states - Silvie R. Kučerová, Sarah L. Holloway and Holger Jahnke - brings the basic overview of the evolution of the discipline geography of education. It delineates three phases in its development and concerns the essential paradigms and research issues in each of the phases. It draws out both linkages across and disparities between geographies of education in different language traditions: German-language, Francophone, and Anglophone oeuvres, as well as more recent research in Eastern Europe.

It is followed by the contributions developing the above three areas of geography of education. The highest share of articles is devoted to the topics referred to in point

\section{(1): Educational provision and restructuring.}

Tanja Mayer, Viktor Geist, Vera S. Pohl, Judith Schwarz, and Thomas Koinzer write about the parental school choice. To follow up on similar research conducted in several other countries, the authors carried out semistructured interviews with parents in the capital city of Germany. They took a distinctive look at the dilemmas that Berlin parents face about being "good parents" by choosing the "best" school with a milieu-related environment for their child versus being "good citizens" by choosing a "local" public school with a large proportion of students belonging to another social class or ethnic group.

The article by Mariella Knapp, Michaela Kilian and Tamara Katschnig deals with the spatial impacts of educational policy in Austria. The authors operate with the conception of Learning Support Spaces (e.g. student cooperation, student-teacher relationships), perceived as a construct for researching the relationship between education policies and their spatial significance. Following Löw's sociological theory, space is seen as a relational arrangement of social goods and persons at given places. Using the example of the introduction of the New Middle School (NMS) as a new school type in Austria, and based on the longitudinal data of a national evaluation project (NOESIS), the article aims to clarify the extent to which, and how, student Learning Support Spaces are perceived as local social conditions inside and outside school, and how this can explain changes in the educational aspirations of students.

The article by Dominik Dvořák, Petr Meyer, Silvie R. Kučerová, Jan Vyhnálek, and Ondrej Šmíd also returns to the topic of the students' aspirations and school choice, analysing inter-school mobility of Czech secondary 
school students. The authors present data on horizontal inter-school mobility of upper secondary students in the Czech differentiated educational system with academic, professional, and vocational tiers and with an elaborate scheme of qualifications. The study is based on administrative microdata from the school register merged with databases carrying geographical information to study the role of the distance to school in qualification and school choices.

Mobility is also the central theme of a study by John Matthias Gulløv and Eva Gulløv. Nevertheless, this article is somewhat on the borderland of the second thematic area: (2) Skills, employability, educational networks, knowledge in space. The article explores the role of education as well as the social dynamics behind the process of youth's leaving homes for education from a peripheral rural community in Denmark. It examines how children gradually come to doubt the local opportunities and become alienated to local life. Based on anthropological fieldwork, the authors show how daycare institutions, schools, and youth education play an essential role in this process.

Hernán Cuervo's article leaves the European ground and focuses on professionals' networks in education in Australia. The author uses the indications that rural education in Australia has been long facing staff issues and low interest of new teachers to work in rural areas. To examine this problem, the author draws on data from semi-structured interviews with pre-service teachers undertaking rural school placement. The aim is to address rural school staffing through a bi-dimensional social justice approach by drawing on a politics of distribution and recognition. While distributive justice has always been at the centre of the problem, it is argued that a solution might also encompass a politics of recognition that puts "place" as a significant category to understand the complexities of rural staffing.

In the end, one of the studies presents the issue of (3) Subjectivities in learning spaces, especially the topics concerning the perception of space by an individual and construction of space: the team of Canadian authors Anne M.C. Godlewska, Laura M. Schaefli, Melissa Forcione, Christopher Lamb, Elizabeth Nelson, and Breah Talan. Canada has long been a colonial country. In the $20^{\text {th }}$ century, with the adoption of multiculturalism and a global peacekeeping mission, it seemed to embrace a new ethos. The authors' study of the knowledge, ignorance and social attitudes of existing undergraduate students at Queen's University in Ontario suggests that students in this part of Canada are educated to misunderstand the fundamental geographies of 
Indigenous peoples, their land, and their identity. The authors use a written survey among students to check and verify the truth of their assumption.

We believe that the readers will find their "cup of tea" in this collection of various scopes and methodological approaches from different parts of the world and will also find this varied mosaic of texts interesting as one whole.

\section{References}

Claval, P. (1998). An introduction to regional geography. Oxford: Blackwell.

Crang, M., Thrift, N. J. (Eds.). (2000). Thinkig space. London \& New York: Routledge. Holloway, S., \& Pimlott-Wilson, H. (2014). Enriching children, institutionalizing childhood? Geographies of play, extracurricular activities, and parenting in England. Annals of the Association of American Geographers, 104 (3), 613-627.

Leitner, H., \& Miller, B. (2007). Scale and the limitations of ontological debate: A commentary on Marston, Jones and Woodward. Transactions of the Institute of British Geographers, 32(1), 116-125.

Siwek, T. (2011). Percepce geografického prostoru. Praha: Česká geografická společnost. 